\title{
Research on Constructing the University of Application Technology Relying on the Industry Background
}

\author{
Guohua Zhao \\ College of Mechanical Engineering, Hubei University of Automotive Technology, Shiyan 442002, \\ China
}

zgh-33333@163.com

\begin{abstract}
Application technical university is to cultivate applied talents of undergraduate level, to promote direct combination of professional skills and knowledge, and to serve to local economic development and the industry. University of applied technology should have scientific orientation fitting the actual and development needs of the school, and idea in accordance with the law of education. To achieve these goals, we must get rid of the bondage of the original system, centre on the local economy and the enterprise needs, cooperate closely with the enterprise, and rely on the power of the enterprise. Hubei University of Automotive Technology gradually has been clear about the development and construction at the university of application technology, and explore the development route of the University of Application Technology, in the process of practice and theory research of the University of Technology, combined with the experience of common colleges and universities.
\end{abstract}

Keywords: Higher education; application Technology University; Practice exploration; Cultivation of talents.

\section{Introduction}

The University of Applied Technology is proposed in the mid - 1960 - a new type of university, it is the process of industrialization and popularization of higher education with European countries. Typically, the university of applied technology is in German, its characteristic of running is distinct, to aim at practical senior technical personnel to the society, especially to emphasize the students' technical application and development of the cultivation of innovation ability.

As a result, students are required to general goals to achieve the following three aspects: one is to solve specific problems from production and life practice, the second is to complete research and development projects of the new science and technology, the three is to use the new method and new technology in theory and research method of technical production.

Application technology university put forward relatively late in our country, until June 2013 national application technology university (college) alliance was established in Tianjin, university of technology begin to appear. So far, although there have been more than one hundred schools have joined the national application technology university (college) coalition, said it was development toward the application technology of university, but it is not to say that the school is the university of applied technology. University of applied technology in our country is still in the phase of theoretical construction, it is also a concept of development, the ideal mode transformation of newly built undergraduate course colleges and universities in our country in the future, and a kind of bias technology only [1]. So, what is a university of applied technology? Researchers believe that university of applied technology is institutions of higher learning in the application of scientific knowledge and technology as the guide for running a school, training high-level technical skills talents for the society [2]. It should be said that this view reveals the basic connotation of the university of application, therefore, the application technology university should include at least two aspects of content: one is the application of scientific knowledge and technology oriented for running a school, but focus on technical knowledge and application of technological achievements, the education content is given priority to with technology or applied disciplines [3].the second is that talent training goal mainly is to cultivate senior technology talents. 
The education content positioning in the technology or applied disciplines is given priority to, the talent training determine in cultivating senior technical talents, it highlights the technical characteristics, application technology university will be distinguished from other types of technology college. Because, no technical accumulation, no attaches great importance to technology research, development, dissemination and transformation, it let alone application Technology University. So, technology research and development, dissemination and transformation must be a basic characteristic and important mission of the University of Applied Technology.

\section{Development of the university of application technology at abroad}

The evolution of the medieval universities abroad come into being application Technology University, it is the result of social interaction of many factors. The development of industry and commerce, the rise of cities and the emergence of the scholastic philosophy plays an important role for the development of the university in different degree. The industrialization period, the University of a Batch of direct service for the industrial and agricultural production appeared, higher education started out of "ivory tower" to serve economic and social development. The university attaches great importance to the basic theory research, not only pay more attention to the application of science research, engineering, applied agriculture and other content included in university courses.

Engineering education as a bridge of communication between science and production obtained rapid development in higher education. Then we have the education economics, management education, also, legal education began to combine with industry to showed a trend of the application; Taking this opportunity to, in higher engineering education as the main body, thought that the cultivation of applied higher education for industrial society. Higher education to cultivate talents of applied appeared for industrial society. The end of the 19th century, American colleges which shall educate talents with application ability $r$ has exceeded the traditional academic university in number. After World War II, with the continuous development of science, technology and social economy, the higher education of developed countries began the process of popularization of higher education, rapid with development and application of science and technology to the field of production, higher education is into the center of society [4].The higher technical education of cultivating talents of various technologies in production field, applied higher education of taking engineering education as the main body also exist at the same time, to distinguish in the type of education, the category of applied higher education extend greatly, it is a kind of new technical education as the main types of applied higher education [5].

Along with the development of society and economy, direction development of higher education is to face popularization, the social and economic development demand for people to put forward the "lifelong learning", under the trend of the differentiation, the type of higher education will inevitably lead to the diversification of institutions of higher learning, mainly, the implementation of this kind of applied higher education form a new university, university of applied technology as the inevitable outcome of the development of popularization of higher education arises at the historic moment, and great contribution has made to national economic and social development, such as the Ur University of Science and Technology Application in German.

\section{Our practice exploration on the university of application technology}

\subsection{Experimental unit of undergraduate education of engineering technology}

Since our school was selected into the colleges and universities of "the education plan of the second batch of outstanding engineers "of the Ministry of Education in 2011, first, we chose the three majors in the mechanical engineering institute, materials science and engineering institute and automotive engineering institute as the experimental class of "outstanding engineers training plan", and then established one national comprehensive reform pilot professional unit, eight "strategic emerging in Hubei province (pillar industry talents cultivation plan" professional, 6 provincial 
professional comprehensive reform pilot. The pilot professional construction in the course mode, teaching method, practice curriculum reform, the teacher's troop construction has carried out a series of reforms, and has established good cooperative relationship with unit of employ persons.

\subsection{Application technology as the guide of the construction of disciplines}

Thought the automobile industry and the local regional economic and social development services for the principle, to adapt to the change of industrial structure of Hubei province, a professional system of applied science is set up. Relying on the idea of subject professional construction, application oriented, supported by discipline, professional development is promoted. On the basis of the above principles, combined with the "twelfth five-year" development plan of Hubei province and the advantages and characteristics of automobile industry of Hubei province college, the existing professional is transformed, according to the specialty construction and professional training to classify, gradually the structure of academic disciplines is improved.

\subsection{The talent training scheme of the application technology}

The theory of applied undergraduate education research and pilot reform of professional experience used in the 2014 version of the undergraduate program. Training objectives from three aspects as knowledge, ability and quality description clearly put forward the professional basic skills and the requirements of the core application ability; The students participate in extra-curricular activities and disciplines of science and technology competition credits alternatives and related courses, acquire the qualification of professional (technology) and the related course credits alternative [6]; The concept of integrated curriculum reform. Is put forward.

\subsection{The reform of teaching methods}

To college physics teaching content and higher mathematics (public foundation courses), we reform practice, in enough, practical and usable the principles of implementation in the teaching. In the process of Professional Courses teaching, explore the reform of teaching method, reform pilot unit according to the characteristics of the students, combination idea of applied education teaching, explore teaching form of the integration of theory, experiment and engineering practice. Diversification of teaching method reform especially in the "outstanding engineer's class" has achieved a good effect on students ability, now schools are summed up and promoted the use.

\subsection{Teach-study-research cooperation between University and Enterprise}

(1)Industry-academy co-operative education base

School attaches great importance to base on industry advantage, innovates actively university enterprise cooperation mode. Dongfeng automobile company provides co - operative education base for the school, the two sides to build automobile energy saving technology innovation center, one the national engineering technology research center sub - center, four provincial engineering technology research center, three the province research and development center, two state - level engineering practice education center, one national college students' education practice base off-campus, eighty-one production-study-research cooperation base.

(2)Industry-academy co-operative training double quality teacher

On the one hand, the cooperative enterprise can provide opportunities of field practice for the young teachers, increasing practical experience, improving skills solving and finding problem in practice and greatly promoting the teaching level; On the other hand, rich practical experience and technical personnel engaged in the work of teaching and management can be hired as a part-time teachers from the enterprise, to enrich the teacher body in our school; At the same time, through the cooperation with enterprises, graduation design topic is derived from the engineer and project, and implement the internal and external double tutorial system, further improving the students ability to solve practical engineering problems. In recent years, the school has established a comprehensive cooperation with local governments and related enterprises, has built off-campus practice bases more than 160 . We signed related agreements with hundreds of companies, to be listed off-campus practice teaching base. This way of the combination of theory and practice greatly has stimulated the students' study enthusiasm. 


\section{Conclusion}

The graduates of Hubei University of Automotive Technology is obviously welcomed by society in recent years, with its large engineering consciousness and practice ability, high comprehensive quality and innovation consciousness, Employment agreement is the first for four consecutive years in provincial colleges and universities. They have become the backbone of national relative industry, especially the auto industry, the school is known as "the cradle of automobile engineers".

\section{References}

[1] Changlin Hou, Jing Luo, Dan Ye. The Development and Orientation of Newly-built Universities from Application-oriented Perspective. Educational Research. Vol.4(2015) No. 4, p. 61-69

[2] Zhenglin Lu, Yongan Gu. Analysis on Several Problems of Application-oriented University, Vocational and Technical Education. Vol.34(2013) No.34,p. 5-11

[3] Yingjun $\mathrm{Xu}$. The Characteristics and the Way to the Future of Technology- applied Universities. HigherEducati on Research \& Evaluation. Vol.5(2007), p. 64-67

[4] Jieqing Cen. Research on the Training Mode of German University of Applied Technology. Industry and Information Technology Education. Vol. 9 (2013) No. 9, p. 60-63

[5] Tianyou Hu. Logic and Problems of the Construction of Application-oriented University. China Higher Education Research. Vol.5(2013), p. 64-67

[6] Yi Liu, Ritao Zhang. Study on the Evaluation Index System of Undergraduate Education Quality in Application-oriented College. Journal of Yangzhou University (Higher Education Study Edition). Jun.2009. Vol. 13 No. 3, p. 14-17 